\title{
UJĘCIE KATEGORII U NICOLAI HARTMANNA
}

Zagadnienie kategorii zajmuje centralne miejsce w hartmannowskiej filozofii. Swiat bowiem jako całość jest zrozumiały wtedy, kiedy zna się jego elementy, tzn. elementy budowy, kategorie i ich relacje ${ }^{1}$. Swoje prace ontologiczne określa Hartmann wprost jảko analizę kategorialną ${ }^{2}$; inne - jak np. Grundzüge einer Metaphysik der Erkenntnis, Ethik, zwìaszcza część trzecią, czy Das Problem des geistigen Seins — stanowią opracowanie poszczególnych kategorii. W nauce o kategoriach chodzi Hartmannowi o sprecyzowanie pojęcia kategorii i podział kategorii. Opracowując te tematy daje wyraz swemu przekonaniu, że filozofia jest po prostu nauką, której problemy w ciągu dziejów ciągle się wzbogacają i w której - mimo aberracji - zbliżamy się do coraz to bardziej zadowalających rozwiązań; filozofowanie jego jest trzeźwym i obiektywnym badaniem dotyczącym całokształtu rzeczywistości ${ }^{3}$, w której człowiek zajmuje skromne miejsce ${ }^{4}$. Hartmann usiłuje dać rozwiązanie w przedmiocie kategorii, które odpowiadałoby dzisiejszemu stanowi wiedzy. W tym celu uwzględnia dotychczasowe osiągnięcia w tej dziedzinie ${ }^{5}$; momentem jednak charakterystycznym jego nauki o kategoriach jest ścisłe oparcie się o tzw. „concretum" ${ }^{6}$.

1 J. Endres, Der Schichtengedanke bei N. Hartmann, w: "Divus Thomas" (Freiburg) 25/1947, 84.

2 Zur Grundlegung der Ontologie, Berlin und Leipzig 1935; Der Aufbau der realen Welt, Berlin 1940; Philosophie der Natur, Berlin 1950.

3 Mam na myśli twórczość filozoficzną N. Hartmanna po roku 1921. Jest to data ukazania się jego Grundzüge einer Metaphysik der Erkenntnis, którym to dziełem Hartmann zrywa $\mathrm{z}$ neokantyzmem marburskim i zapoczątkowuje oryginalny sposób uprawiania filozofii.

4 Podkreśla to Wolfgang Stegmüller, Hauptströmungen der Gegenwartsphilosophie, Stuttgart $1960^{2}, 243$.

5 Por. np. Der Aufbau der realen Welt, Meisenheim $1949^{2}$ 1-40. (cyt. odtąd jako $A r W)$.

$6 \mathrm{~W}$ jakimś bardzo syntetycznym skrócie można by powiedzieć, że „concretum" to dostrzeżone dane obiektywne. 
Historycznie rzecz biorąc podstawowym problemem $\mathrm{w}$ nauce o kategoriach jest zagadnienie, czy są one subiektywnymi formami poznania rzeczywistości - jak uczył Kant i cała filozofia przez niego inspirowana aż do neokantyzmu szkoły marburskiej i badeńskiej - czy też są czymś obiektywnym, niezależnym od podmiotu poznającego. Według Hartmanna kategorie są zarówno formami umysłu jak i formami bytu czy determinacjami przedmiotowymi. Podział ten na dwa rodzaje kategorii nie wydaje się być synkretyzmem, ale oryginalnym pomysłem Hartmanna ${ }^{7}$.

Stanowisko, jakie zajmuje Hartmann w nauce o kategoriach i miejsce, jakie ta nauka zajmuje $\mathrm{w}$ filozofii hartmannowskiej, zdają się usprawiedliwiać to, co napisał Heinz Heimsoeth, że „na podstawie badań N. Hartmanna należałoby zupełnie od nowa napisać historię nauki o kategoriach" 8.

I.

Hartmann podziela w teorii poznania stanowisko bezwzględnie obiektywistyczne ${ }^{9}$ : poznanie jest ujęciem czegoś, co istnieje przed poznaniem i niezależnie od poznania ${ }^{10}$. Konsekwentnie w nauce o kategoriach zaj-muje się Hartmann nie formami rozumu, ale strukturalnymi podstawami świata realnego; stąd nauka o kategoriach w jego ujęciu ma charakter ontologiczny, tzn. bada ontyczne podstawy bytu wziętego w sensie dystrybutywnym ${ }^{11}$, albo też szuka jego zasad konstytutywnych ${ }^{12}$. Analiza kategorialna docieka wewnętrznej struktury bytu pytając o to, co konstytuuje byt i jaka jest jego struktura ${ }^{13}$. Są to pytania natury ontologicznej. W ontologii zaś chodzi o fundamentalne orzeczniki o bycie jako takim. Kategorie bytu są zasadami bytu. Zasadą w rozumieniu Hartmanna jest to, co stanowi podstawę determinacji bytu konkretnego względnie też jest to tego rodzaju uwarunkowanie, na mocy którego rzeczy są takimi, jakimi są ${ }^{14}$. Kategorie są zasadami powszechnymi

7 Pewne zastrzeżenia co do oryginalności dychotomii $w$ podziale kategorii mogą się nasunąć w związku ze studium Hartmanna pt. Heinrich Maiers Beitrag zum Problem der Kategorie w: Kleinere Schriften, t. II. Berlin 1957, 346-364. (cyt. odtąd jako $K S$ ).

8 Zur Geschichte der Kategorienlehre w: H. Heimsoeth u. R. Heiss, Nicolai Hartmann. Der Denker und sein Werk, Göttingen 1952, 147.

9 Johannes Hessen, Lehrbuch der Philosophie, t. I, München-Basel 19502, 271.

10 N. Hartmann, Grundzüge einer Metaphysik der Erkenntnis, Berlin $1965^{5}$, 1. (cyt. odtąd jako $M E$ ).

${ }_{11}$ Tadeusz Czeżowski, O metafizyce, jej kierunkach $i$ zagadnieniach, Toruń 1948, 69-70. Użycie terminu „,byt” w sensie dystrybutywnym znaczy tyle, co „,cokolwiek", jakiś przedmiot, stąd: byt jest nazwą dla jakiegokolwiek przedmiotu. Sens kolektywny terminu ,byt” oznacza wszystko, np. „metafizyka jest nauką o bycie” znaczy, że jest nauką o wszystkim, a więc o bytach wszelkiego rodzaju.

12 ArW, 41-42.

13 Tamże, 42.

14 Tamże, 78. 81. 
i konstytutywnymi ${ }^{15}$, które da się wyrazić jedynie w formie orzeczników. Orzeczniki jednak nie są identyczne z samymi zasadami jako takimi, lecz mają jedynie wartość zbliżenia się do samych zasad. Nie można przeto utożsamiać pojęć zasad bytu z samymi zasadami ${ }^{16}$.

Hartmann używa różnych określeń dla wyrażenia tego, czym kategorie są. Nazywa je ,fundamentami bytu” 17, ,podstawami bytu” 18, ,zasadniczymi właściwościami bytu” 19, ,zasadami bytu” 20, ,wewnętrznymi principiami" 21.

Relację ich do podmiotu poznającego można by określić w ten sposób: kategorie jako konstytutywne, wewnętrzne i strukturalne zasady bytu ${ }^{22}$ są transcendentne w stosunku do podmiotu poznającego - istnieją niezależnie od wszelkiego poznania. Poznanie bowiem nie jest tworzeniem przedmiotu, lecz ujmowaniem czegoś, co jest przed aktem poznawczym i istnieje niezależnie od niego ${ }^{23}$.

Skoro kategorie w ujęciu Hartmanna są zasadami bytu, to dlaczego Autor nazywa je kategoriami, a nie po prostu ,,zasadami” czy ,,principiami”? Termin bowiem ,kategoria” znaczy tyle, co „orzecznik”. Orzeczniki jako następstwo orzekania, a więc sądu, należą bardziej do dziedziny myśli niż bytu. Autor przyznaje, że - historycznie rzecz biorąc - wyraz „kategoria” przemieszczał się w stronę logiki 24. Podtrzymując mimo to jego aktualność - jak się wydaje dla wyrażenia jakiegoś subiektywnego momentu naszej wiedzy o bycie i jego zasadach - argumentuje w ten sposób:

To, co o bycie orzekamy, jest czymś zewnętrznym w stosunku do bytu. Rzeczy bowiem posiadają swe własności i determinacje niezależnie od naszego sądu o nich. Różne terminy na wyrażenie zasad bytu wnoszą w rzecz samą określone wyobrażenia czy zdeterminowane sposoby pojmowania. Termin ,kategoria" natomiast nie zawiera żadnych założeń co do treści. Termin ten znaczy tylko tyle, co aktualnie o bycie można

15 Hartmann, Neue Wege der Ontologie, Stuttgart 19644, 12. (cyt. odtąd jako NWO). Por. również $M E$, 259: „Kategorien des Seins sind nicht, was das Wort ursprünglich besagt, Aussagen oder Prädikamente möglicher Urteile. Sie sind Bestimmtheiten, Formen oder Gesetze des Gegenstandes, reine Objektprinzipien, die dem Seienden an sich eigentümlich sind."

${ }_{16} A r W, 14$ oraz $M E, 261$ : „Auch zwischen Seinskategorien und Kategorienbegriffen besteht daher der unendliche Progress der Annäherung."

17 ArW, V: Seinsfundamente.

18 Tamże, 2: Seinsgrundlagen.

19 Tamże: Grundbestimmungen des Seienden... in inhaltlicher Sicht.

20 Tamże, 3: Prinzipien des Seins.

21 Tamże, 13: innere Prinzipien.

22 Tamże, 2.

23 $M E$, 1: ,...Erkenntnis... [ist] ...ein Erfassen von etwas, das auch vor aller Erkenntnis und unabhängig von ihr ist." Por. również ArW, 7: „,..Erkennen ist das „Erfassen” eines Seienden..., das auch unabhängig von ihm ist, was es ist..." $24 \mathrm{ArW}, 4$. 
orzekać; sam zaś byt i jego podstawy pozostają indyferentne w stosunku do twierdzeń o bycie ${ }^{25}$.

W dalszym ciągu swej argumentacji Hartmann dowodzi, że w pojęciu kategorii tkwi przeświadczenie, że orzekają one coś o samej rzeczy. To „,coś” oznacza właściwość rzeczy albo przedmiotu, o którym kategorie coś orzekają. Cecha orzekana przynależy do przedmiotu niezależnie od faktu jej orzekania czy nieorzekania ${ }^{26}$.

Zasady bytu jednak nie są nam dane bezpośrednio, przeciwnie: naszemu poznaniu są dostępne jedynie pewne aspekty tych zasad i to aspekty odpowiednie danemu stadium analizy kategorialnej; wobec tego należy podkreślić, że do istoty omawianego pojęcia kategorii należą trzy momenty:

1. wyraźnie zarysowana i obiektywna postać zasadnicza poznawanego bytu czy jego zasad - co jest momentem pozytywnym w pojęciu kategorii;

2. niezupełność, niedokładność i ewentualna jednostronność w ich poznaniu - a więc momenty negatywne tegoż pojęcia;

3. możliwość błędu jako konsekwencja tzw. momentów negatywnych,

$\mathrm{Z}$ tak postawionego zagadnienia kategorii płyną następujące wnioski:

To, co my uważamy za zasady, to nie są zasady same jako takie. Należy odróżnić zasady jako takie od pojęć tychże zasad, które są jedynie próbą ujęcia zasad jako takich. Wobec tego użycie terminu „kategoria” zakłada znajomość powyższych rozróżnień, co Hartmann reasumuje w zdaniu: „[Kategorie] ... są orzecznikami, ale jednocześnie są czymś więcej niż tylko orzecznikami; są principiami, ale równocześnie czymś mniej niż same zasady" ${ }^{27}$.

Kategorie są powszechne - chodzi tutaj o specyficzną powszechność kategorialną - i „determinują" rzeczywistość 28.

Powszechne są one dlatego, że nie stanowią zasady dla jakiegoś konkretnego, jednostkowego bytu, lecz dla rzeczywistości w ogóle czy dla jakiejś większej grupy bytów konkretnych. Przykładowo: kategorie fundamentalne dotyczą bytu w ogóle, tak realnego jak i idealnego. Kategorie szczegółowe natomiast odnoszą się do jednego tylko czy kilku typów bytu ${ }^{29}$. Zakładając wspomnianą powszechność kategorii Autor twierdzi,

25 ME, 259-270.

26 ArW, 5.

27 Tamże, 14.

28 Na marginesie takiego ujęcia kategorii J. Endres (art. cyt., 84 odnośnik 4) czyni uwagę, że hartmannowskie pojęcie kategorii różni się od pojęcia kategorii znanego scholatyce. Scholastyka bowiem przyporządkowała kategoriom byt pełny, a nie jego fizyczne czy metafizyczne części ani też byty powstające czy rozwijające się.

29 Hartmann nie używa wyrażenia „typ” bytu, lecz mówi o warstwach bytu. Por. ArW, 188-200. 
że ,istnienie" ich ${ }^{\mathbf{3 0}}$ jest wprawdzie $\mathrm{z}$ jednej strony bezczasowe albo ponadczasowe i niezależne od przypadków realnych, natomiast z drugiej strony są one tylko w rzeczach konkretnie istniejących, skoro - posługując się wyrażeniem Autora - z rzeczy można je ,wyjąć” 31. Z tego wynika, że Hartmann nie przyjmuje jakiejś iuxtapozycji bytu kategorialnego obok bytu konkretnie istniejacego ${ }^{32}$. Kategorie mają po prostu „,istnienie kategorialne" 33 , którego momentem charakterystycznym jest „bycie zasadą”, co wyraża się w tym, że w stosunku do concretum, pojętego jako ta rzeczywistość, jaką ujmuje świadomość pod kątem rozwoju jaki przeszła ${ }^{34}$, są czynnikiem determinującym. Innymi słowy: kategorie są tym, od czego byt konkretny zależy.

Jak należy pojąć tę kategorialną determinację?

Hartmann pisze wprawdzie, że ,determinacja jest sposobem wyznaczenia jednego [bytu] przez [byt] inny" 35, ale takie sformułowanie jest w gruncie rzeczy tautologią. Spośród form determinacji najbardziej znane są: determinacja przyczynowa i determinacja celowa. Determinacji kategorialnej nie da się sprowadzić ani do pierwszej ani do drugiej. Przyczyna bowiem już przed spowodowaniem ${ }^{36}$ skutku istnieje jako byt samodzielny, podczas gdy kategorie nie istnieja samodzielnie poza concretum, które determinują. Bytują jedynie ,w” concretum i istnieją „dla" concretum 37. Aby wyeliminować podejrzenie o dualizm zasadabyt Autor wyjaśnia, że zasady są czymś immanentnym rzeczom i dają się wyróżnić tylko w abstrakcji, w rzeczywistości bowiem relacja zasada-concretum stanowi jedność ${ }^{38}$. Stąd determinacja kategorialna jest determinacją szczególnego rodzaju. Podobnie jednak jak żadnej z form determinacji nie da się bez reszty pojaćc ${ }^{39}$, tak też i tej determinacji nie da się adekwatnie wyjaśnić. Relację zasada-concretum można jedynie opisać używając wyrażeń ,znaczą”, „determinują”, „są”. Istoty jednak tej relacji opisy te nie wyrażają poza stwierdzeniem, że ,istotą" kategorii jest ,bycie zasadą" 40. Autor usiłuje relację zasada-concretum objaśnić

30 Dokładnie: kategorie nie istnieją, lecz ,znaczą”. Por. np. Philosophie der Natur, Berlin 1950, 145 (cyt. odtąd jako PhN).

31 ArW, 48.

32 NWO, 61.

$33 \quad \mathrm{ArW}, 53$.

34 Tamże, 593.

35 Tamże, 309: „Determination ist... Bestimmtsein des einen durch ein anderes...”

36 Nie dyskutuję tutaj natury owego „powodowania” skutku przez przyczynę.

37 Tamże, 78: „Das Prinzipsein der Kategorien heisst eben dieses, dass sie kein Fürsichsein haben, sondern nur ein Sein ,für" anderes: oder auch, dass sie das, was sie an sich sind, nur ,für" das Concretum und „an" ihm sind... Und das bedeutet weiter, dass das Sein der Kategorien in der Bestimmung des konkreten Seienden aufgeht. Kategorien haben kein anderes Sein als die von ihnen ausgehende das Concretum betreffende Determination."

38 Tamże, 77.

39 Tamże, 425.

40 Tamże, 419-426. Autor omawia w tym rozdziale prawo ważności zasady. 
porównując ją z relacją, jaka zachodzi między tym, co powszechne, a tym, co indywidualne ${ }^{41}$. To, co powszechne istnieje jedynie w bytach konkretnych, indywidualnych. Jest niejako „wtopione” w skonkretyzowaną rzeczywistość. Byt powszechny nie istnieje obok bytu jednostkowego. I kategorie również nie są jakąś postacią odrębną od konkretnych przedmiotów. Stanowi to, zdaniem Hartmanna, antynomię i to - w systemie tzw. ontologii krytycznej - nierozstrzygalną: byt niesamodzielny, jakim są kategorie, determinuje byt samodzielny czyli concretum ${ }^{42}$.

Reasumuję: kategorie w ujęciu i rozumieniu Hartmanna są powszechnymi i konstytutywnymi zasadami bytu, są czymś obiektywnym, istnieją niezależnie od podmiotu poznającego. Wobec tego nauka o tak pojętych kategoriach ma charakter ontologiczny, bo bada ontyczne podstawy bytu. Hartmann dlatego nazywa to, co konstytuuje byt, kategorią, by stonować swoje stanowisko realizmu teoriopoznawczego wskazaniem na fakt, że w poznaniu zasad zbliżamy się aproksymatywnie do zasad jako takich, nie ujmując ich całkowicie ani co do treści ani co do zakresu. Nie ma bytu kategorialnego obok bytu konkretnie istniejącego: kategorie są tym, od czego byt konkretny zależy.

II.

Hartmann wyróżnia dwa typy kategorii: kategorie przedmiotu, które albo są kategoriami bytu realnego albo kategoriami bytu idealnego oraz kategorie poznania.

Kategorie poznania to subiektywne uwarunkowanie podmiotu poznającego ${ }^{43}$ albo — jak Hartmann sam lapidarnie je określa ${ }^{44}$ — ,narzędzia poznania", które uświadamiamy sobie w refleksji teoriopoznawczej 45.

Aby bliżej scharakteryzować kategorie przedmiotu, należy zapoznać się z interpretacją rzeczywistości, dokonaną przez Hartmanna ${ }^{46}$. Otóż rzeczywistość dzieli się na byt realny i idealny ${ }^{47}$. „Realność” i ,idealność" to różne sposoby istnienia bytu.

41 Tamże, 425. Hartmann zastrzega się jednak, że nie posiadamy ani pojęć ani wyobrażeń, które by jednoznacznie mogły unaocznić tę relację.

42 Tamże, 423: „Die Antinomie lässt sich kurz so aussprechen: das Prinzipium ist unabhängig vom Concretum, weil vielmehr das Concretum von ihm abhängig ist; und zugleich ist es doch abhängig vom Concretum, weil es nur relativ auf dieses besteht. Beides liegt im Wesen des Prinzipseins."

$43 \quad M E$, 379: Wesensgesetze der Erkenntnis.

44 Teleologisches Denken, Berlin $1966^{2}$, 52. (cyt. odtąd jako DT).

45 O pochodzeniu tych kategorii poznania w świadomości por. N. Hartmann, Die Erkenntnis im Lichte der Ontologie w: KS, t. I., Berlin 1955, 160 oraz PhN, 115. Problem ten rozwinęła i przeanalizowała krytycznie Ingeborg Wirth, Realismus und Apriorismus in Nicolai Hartmanns Erkenntnistheorie, Berlin 1965, 100-103.

46 Por. krytyczny artykul J. Endresa, art. cyt., 84-96.

47 Nie mówię tutaj o bycie intencjonalnym, będącym pojęciem teorio-poznawczym. Hartmann mówiąc o bycie realnym i idealnym rozważa tę kwestię w płaszczyźnie ontologicznej. 
Byt idealny osiągamy poznawczo jedynie w myśleniu pojęciowym. $\mathrm{W}$ stosunku do bytu realnego nie jest on bytem samodzielnym - jak to ma miejsce np. w systemie Platona. Przeciwnie: łączy się z bytem realnym, a stosunek bytu idealnego do bytu realnego można by mniej więcej ująć w ten sposób, że byt idealny jest niejako „wtopiony” w rzeczywistość. Odrębność jednak sposobu istnienia bytu idealnego warunkuje istnienie własnych kategorii szczegółowych. Na marginesie tylko zaznaczę, że odrębność obu sfer bytu wyraża się ich stosunkiem do czasu i zindywidualizowania. Byt idealny jest niezmienny, ponadczasowy i ogólny ${ }^{48}$. Podstawą przyjęcia obok bytu realnego także i bytu idealnego jest fakt, że byt idealny tak samo jak byt realny odznacza się samodzielnością gnozeologiczną. Samodzielnością gnozeologiczną, zwaną przez Hartmanna ,wsobnością", jest bytowanie przedmiotu niezależnie od podmiotu poznającego ${ }^{49}$; innymi słowy: byt, któremu przypisuje się taką samodzielność, istnieje niezależnie od faktu jego poznania w ogóle ${ }^{50}$. Hartmann wyraźnie akcentuje to, że byt idealny narzuca się świadomości, która w stosunku do niego jest ,bezsilna” w tym znaczeniu, że nie może go dowolnie zmieniać i niezależnie od tego, czy o nim myśli czy też nie, jest taki jaki jest, posiada cechy owej samodzielności gnozeologicznej ${ }^{51}$. Byty idealne stają się czymś intencjonalnym dopiero przez poznanie ${ }^{52}$, przy czym przez ,bytowanie intencjonalne" rozumie bytowanie uzależnione od umysłu poznającego, a więc ,bycie-dla-mnie”, które jest pozbawione samodzielności gnozeologicznej ${ }^{53}$. Dla Hartmanna samodzielność idealna jest faktem tak z punktu widzenia etycznego jak i teoretycznego ${ }^{54}$. Sposób prezentowania się tych przedmiotów idealnych naszej poznającej świadomości Autor przykładowo opisuje tak: świadomość - o ile skierowuje się ku sferze tego co matematyczne - doznaje oporu ze strony tworów matematycznych i stwierdza, że przedmioty te nie poddają się jej samowoli. Z tego Hartmann wnioskuje, że bytom idealnym — istocie rzeczy, przedmiotom matematycznym i logicznym oraz wartościom - przysługuje idealna samodzielność gnozeologiczna „,słabsza" co prawda od samodzielności bytów realnych. Ponadto jednak przedmioty idealne stanowią ontycznie równoprawną dziedzinę obok przedmiotów realnych, tzn. że Hartmann przyznaje tym przedmiotom oprócz samodzielności gnozeologicznej również i samodzielność ontolo-

48 Zur Grundlegung der Ontologie, Berlin und Leipzig 1935, 242-322 (cyt. odtąd jako GO). jako $E$ ).

49 GO, 249-250. Por. także Ethik, Berlin 19624, 149 odnośnik (Ethik cyt. odtąd

$50 M E, 484,559$.

51 Tamże, 478-481. 559.

52 Tamże, 480-481.

53 Tamże, 479.

$54 \quad E, 152-154$. 
giczną, polegającą na ich istnieniu bez jakiegokolwiek odniesienia do świadomości 55. Niemniej trzeba zwrócić uwagę i na tę okoliczność, że właśnie w teorii bytów idealnych Hartmanna zauważa się wahania ${ }^{\mathbf{5 6}}$, a niektórzy jego krytycy twierdzą wprost, że w tej kwestii dostrzega się ewolucję jego poglądów ${ }^{57}$.

Rzeczona idealność bytu może być albo idealnością „,wtopioną” (anhängende Idealität), co zachodzi np. w odniesieniu do istoty rzeczy ${ }^{58}$ albo też ,idealnością wolną", którą to idealnością odznaczają się przedmioty matematyczne i logiczne oraz wartości ${ }^{59}$.

Zdaniem Hartmanna myślenie naiwne przyznaje samodzielność gnozeologiczną jedynie bytom realnie istniejącym i to dlatego, że nasze naturalne odczucie skierowane jest wyłącznie na byt realny. Byt idealny zaś przedstawia się nam jako coś, co nie posiada pełnego charakteru bytowego. Pogląd ten może odwoływać się do bezpośredniego doświadczenia wewnętrznego, w którym te przedmioty występują, do złudzenia ich immanencji czy też do faktu ich charakterystycznej bliskości w stosunku do świadomości. Mimo że Hartmann przyznaje bytom idealnym jedynie samodzielność względną ${ }^{60}$ i mimo że byty idealne to niekompletne komponenty przedmiotów ${ }^{61}$, hartmannowskiej teorii bytu idealnego można wytknąć poważne niedopowiedzenia: nie sposób zrozumieć zakotwiczenia bytu idealnego $\mathrm{w}$ bycie realnym $\mathrm{z}$ jednoczesnym przyjęciem transcendecji idealnej obok i niezależnie od transcendencji realnej; twierdzeniu, że przedmiot idealny jest irrealny a jednocześnie „wsobny” można postawić zarzut, że daje dowód do błędu subiektywistycznego, identyfikującego przedmioty idealne $\mathrm{z}$ przedmiotami realnymi $\mathrm{w}$ znaczeniu jakiegoś podporządkowania tych ostatnich pierwszym albo też odwrotnie: twierdzenie to może stać się powodem błędu realistycznego, który byty idealne podporządkowuje bytom realnym.

Byt reainy natomiast, jako podległy czasowi i zmienny, jest konkretny, zindywidualizowany i niepowtarzalny ${ }^{62}$. Jest nim to wszystko, co stanowi świat przestrzenny i nieprzestrzenny, a więc byty organiczne i nieorganiczne, psychiczne i duchowe ${ }^{63}$. Stąd rzeczywistość dzieli się

$55 M E$, 480. 481. 505. Por. również cyt. studium I. Wirth, 64.

$56 \quad E, 149$.

57 Ewald Th. van den Vossenberg, Die letzten Gründe der Innerweltlichkeit in Nicolai Hartmanns Philosophie, Roma 1963, 8.

58 W przedmiocie realnym wyróżnia Hartmann strukturę „podstawową”, identyczną z bytem idealnym, i "dodatkową" strukturę realną, czyli to wszystko, co wykracza poza granice bytu idealnego, a więc momenty alogiczne, sprzeczne, nie będące wartością. Por. $M E, 313-314$.

$59 \quad M E, 481-484$.

60 GO, 265.

$61 \mathrm{PhN}, 205$.

62 NWO, 22.

63 Tamże, 36-37. 
na cztery warstwy zasadnicze z kolei jednak tak zróżnicowane, że tworzą całą hierarchię bytów ${ }^{64}$. Każdej z tych warstw rzeczywistości są przyporządkowane im właściwe kategorie ${ }^{65}$, które są przedmiotem szczegółowej nauki o kategoriach ${ }^{66}$. Szczegółowa nauka o kategoriach określa naturę poszczególnych warstw rzeczywistości szukając im właściwych kategorii ${ }^{67}$ i stara się uchwycić relacje zachodzące pomiędzy poszczególnymi kategoriami w obrębie danej warstwy rzeczywistości ${ }^{68}$. Przykład: przedmiotem filozofii przyrody są dwie pierwsze warstwy rzeczywistości czyli to, co stanowi świat przestrzenny. Filozofia przyrody zajmuje się kategoriami kosmologicznymi, determinującymi warstwę fizyko-chemiczną i kategoriami organologicznymi, które określają warstwę organizmów żywych ${ }^{69}$.

Szczególne znaczenie mają te kategorie, które są wspólne dla całej dziedziny bytu realnego względnie jakiejś większej jego części. Dlaczego? $\mathrm{Z}$ jednej strony są one zasadami bytu, a z drugiej tworzą połączenia pomiędzy poszczególnymi warstwami rzeczywistości ${ }^{\mathbf{7 0}}$. Są to tzw. kategorie fundamentalne ${ }^{71}$. Podmiotowi poznającemu przedstawiają się one jako coś bardzo prostego i samo przez się zrozumiałego ${ }^{72}$. Z racji ich powszechności w stopniu minimalnym tylko można poznać ich naturę ${ }^{73}$. W sposób bardziej skonkretyzowany są one dostępne poznaniu wtedy tylko, gdy pojawiają się w postaci ,przekształconej” na poziomie którejś z warstw rzeczywistości 74. Status tych kategorii fundamentalnych jest szczególnego rodzaju ${ }^{75}$. Tworzą one trzy grupy: kategorie modalności Modalkategorien -, kategorie elementarne o charakterze struktural-

64 Por. do całości zagadnienia ArW, 188-200, a szczególnie 197-200 oraz 200-208. Nie można identyfikować danej warstwy rzeczywistości z koresponđującą z nią warstwą kategorialną i to dla dwóch powodów:

a. kategorie świata realnego są tylko jedne spośród wielu typów kategorii;

b. oprócz tzw. kategorii szczegółowych istnieją również kategorie fundamentalne, które nie przynależą do określonej warstwy rzeczywistości.

65 Tamże.

66 NWO, 39. Każdej warstwie rzeczywistości odpowiadają jej właściwe kategorie, które są momentem odróżniającym jedną warstwę rzeczywistości od drugiej.

$67 \mathrm{Jt}$. tzw. analiza warstw w sensie ścisłym.

68 Tamże, 42.

69 Przykładowo tylko wymienię: czas i przestrzeń stanowią kategorie dimensjonalne. Spośród kategorii kosmologicznych: powstanie (proces) i trwanie (substancjalność), przyczynowość, prawa przyrody, wzajemne oddziaływanie, determinacja centralna, hierarchiczna budowa przyrody, determinacja całościowa. Spośród kategorii organologicznych $\mathrm{m}$. in. podaje determinację organiczną, równowagę organiczną, proces życiowy, tzw. nexus organicus.

70 NWO, 42.

71 Tamże, $52-53$.

72 Tamże, 53. 59.

73 Tamże, 53: „Inhaltlich stellen sie nur ein Minimum greifbarer Bestimmtheit dar. Das ist die Folge der hohen Allgemeinheit."

${ }_{74}$ Tamże. I tylko $\mathrm{w}$ bogactwie ich odmian na poziomie różnych warstw rzeczywistości można poznać, jakie - co do treści - są te kategorie.

75 Tamże, 53 i 61. 
nym - Elementarkategorien, Gegensätze -, prawa kategorialne - Kategorialgesetze.

Kategorie modalności albo skrótowo „modi” dotyczą tylko sposobów istnienia: możliwości, rzeczywistości i konieczności. Te kategorie nie dotyczą struktury świata.

Kategorie elementarne albo skrótowo „przeciwstawności” występują w formie uzupełniających się członów przeciwstawnych. Kategorie te ujmuje Autor w 12 par przeciwstawnych, podzielonych - po 6 - na dwie grupy ${ }^{76}$. Zastrzega się jednak, że ustanawianie jakichkolwiek tablic kategorialnych można ocenić jedynie jako próbę.

Ponieważ prawa kategorialne są prawami budowy świata rzeczywistego, stąd w obrębie nauki o kategoriach przysługuje im szczególne znaczenie ${ }^{77}$. W zależności od stosunku zasady do concretum, nakładania się poszczególnych warstw rzeczywistości na siebie i miejsca poszczególnych kategorii w obrębie danej warstwy rzeczywistości Hartmann formułuje cztery zasady, zawierające $\mathrm{w}$ sobie $\mathrm{z}$ kolei cztery prawa: ${ }^{78}$

1. zasadę znaczenia - Grundsatz der Geltung - według której kategorie są principiami czegoś i są niczym bez concretum, a - odwrotnie - concretum jest niczym bez nich; a oto prawa wynikające $z$ tej zasady:

a. prawo zasady mówi, że istota kategorii polega na tym, że jest ona zasadą determinującą aspekty rzeczy; "byt" kategorii wyczerpuje się w tym jej „być zasadą dla concretum";

b. prawo ograniczonego znaczenia, według którego determinacja kategorii dotyczy bezwzględnie $\mathrm{w}$ granicach danej warstwy $\mathrm{w}$ stosunku do swego concretum;

c. według prawa przynależności do warstwy determinacja ze strony kategorii dotyczy tylko danej warstwy, a poza tą właśnie warstwą determinacja ta może być tylko ograniczona i zmodyfikowana;

d. według zaś prawa determinacji warstwy kategoria determinuje w sposób całkowity concretum danej warstwy;

2. zasadę koherencji - Gesetze der kategorialen Koheränz - w myśl której kategorie jednej i tej samej warstwy łączą się między sobą. I tutaj wymienia cztery prawa kategorialne:

${ }^{76}$ ArW, 230-231:

1. Prinzip - Concretum

Struktur- Modus

Form - Materie

Inneres - Äusseres

Determination - Dependenz

77 Tamże, 220.

Qualität - Quantität

78 ArW, $412-575$.
2. Einheit - Mannigfaltigkeit Einstimmigkeit - Widerstreit Gegensatz - Dimension Diskretion-Kontinuität

Substrat-Relation

Element-Gefüge. 
a. prawo połączeń orzekające, że kategorie danej warstwy bytu determinują concretum w łączności, a nie w izolacji jedna od drugiej;

b. prawo jedności warstwy, według którego kategorie tej samej warstwy są ze sobą treściowo splecione, czy istnieje pomiędzy nimi jakaś nierozerwalna jedność;

c. prawo całości warstwy widzi w tej jedności kategorialnej nie tylko sumę części, ale niepodzielną całość, która stanowi prius przed jej częściami;

d. prawo implikacji, według którego każda kategoria implikuje pozostałe kategorie tej warstwy;

3. zasadę uwarstwienia - Gesetze der kategorialen Schichtung mówiącą, że kategorie warstw niższych rzeczywistości w dużym stopniu zawierają się w warstwach wyższych, ale nie odwrotnie. Bardziej szczegółowo omawiają tę zasadę następujące prawa:

a. prawo powrotu kategorii warstw niższych na poziomie warstw wyższych jako elementy kategorii wyższych;

b. prawo przekształcenia (transformacji): przy powrocie kategorii w warstwach wyższych owe elementy kategorialne doznają przekształcenia, co zależy od koherencji warstwy, do której wchodzą;

c. prawo novum, będące charakterystyką kategorii wyższych, które składają się z niższych elementów kategorialnych, ale nie są sumą tych elementów. Poza elementami kategorialnie niższymi jest w kategoriach wyższych coś specyficznego - novum kategorialne, które decyduje o powrocie niższych kategorii i o ich przekształceniu;

d. prawo dystansu warstw mówi o tym, że powrót kategorii i ich przekształcenia dokonują się w sposób nieciągły;

4. zasadę zależności - Gesetze der kategorialen Dependenz - ujmującą jednostronność zależności kategorii w ich warstwowej hierarchii: wyższe kategorie zależą od kategorii niższych, przy czym ta zależność jest tylko częściowa, pozostawiająca miejsce dla indywidualności — swoistości - kategorii wyższych. Zasada ta implikuje:

a. prawo siły, według którego kategorie wyższe zakładają cały szereg kategorii niższych. Istnieje jednokierunkowa zależność kategorialna od kategorii niższych do wyższych. Ponieważ kategorie niższe są fundamentem kategorii wyższych, dlatego one właśnie są kategoriami silniejszymi. Prawo to jest zasadniczym prawem kategorialnym;

b. prawo obojętności precyzuje status kategorii warstwy niższej w stosunku do wyższej: warstwa niższa jest obojętna w stosunku do warstwy wyższej, warstwa niższa stanowi samodzielną determinację zasad; 
c. prawo materii dotyczy wpływu warstw wyższych w stosunku do warstw kategorialnie niższych. Tam, gdzie zachodzi powrót kategorii i tzw. nadbudowa, kategorie niższe dla kątegorii wyższych stanowią materię. Materia daje kategoriom wyższym możliwość formowania kategorii niższych, ale jednocześnie ogranicza w jakimś stopniu kategorie wyższe. Tam, gdzie zachodzi tzw. nadbudowa, materia staje się tylko fundamentem dla kategorii wyższych, czyli wpływ jej na kategorie wyższe jest jeszcze mniejszy;

d. prawo wolności wreszcie dotyczy tzw. novum kategorialnego, Kategorie wyższe, uzależnione od niższych tylko co do materii czy fundamentu, w swym kategorialnym novum są wolne w stosunku do kategorii niższych, bo novum kategorialne co do swej treści jest formacją górującą. Wolność zachodzi tylko tam, gdzie mamy stosunek słabszego do silniejszego, tzn. tam, gdzie ,to, co jest niższe” jest tylko elementem formacji „wyższej”.

Reasumuję: kategorie fundamentalne są wspólne wszystkim warstwom rzeczywistości względnie prawie wszystkim warstwom. Powtarzają się one na poziomie poszczególnych warstw, ale w postaci ,przekształconej". Oprócz tego każda warstwa bytu ma swoje kategorie szczegółowe, jej tylko właściwe ${ }^{79}$.

III.

Poznanie kategorii jest wysoce złożone. Negatywnie: wiedzy o kategoriach nie zdobywamy na drodze apriorycznej, ani też przez uświadomienie sobie zasad poznania ${ }^{80}$, ani też na drodze empirii. Indukcja, dedukcja, poznanie aposterioryczne i aprioryczne nie stanowią w tym względzie dróg poznania ${ }^{81}$. Pozytywnie: kategorie poznajemy $\mathrm{w}$,,analizie kategorialnej", tzn. poprzez analizę struktury ontycznej przedmiotów i tylko w tym stopniu, w jakim te są nam dostępne ${ }^{82}$. Najogólniej można powiedzieć, że kategorie poznajemy stopniowo na bazie przedmiotów rzeczywistych ${ }^{83}$. Zakłada to, że zasady bytu powinny w jakiś sposób mieścić się W samej rzeczywistości ${ }^{84}$. Ponieważ owe zasady nie są nam dane w sposób bezpośredni, dlatego można do nich dojść jedynie przez ,wgłębianie się" myślowe w rzeczywistość. Dokładniej: do ujęcia tych zasad dochodzimy $\mathrm{w}$ rozumowaniu redukcyjnym ${ }^{85}$. Wynik takiego rozumowa-

79 Por. Katharina Kanthack, Nicolai Hartmann und das Ende der Ontologie, Berlin 1962, 18-21.

80 NWO, 17.

81 Tamże, 18.

${ }^{82}$ ArW, 55: „Der analytische Rückschluss... bildet auf allen Gegenstandsgebieten den Zugang zu den Kategorien."

83 Tamże, 13 .

84 Tamże, 16.

85 Tamże, 19. 
nia jest hipotetyczny. Hipotetyczność tę można zmniejszyć, gdy dysponujemy jakimś szerszym materiałem empirycznym tzn. jeżeli wykażemy większą ilość przedmiotów potwierdzających ${ }^{86}$. Konkluzją tak pojętej analizy kategorialnej jest postulat ciągłej krytyki osiągniętych rezultatów poznawczych ${ }^{87}$.

Historycznie rzecz biorąc analizę kategorialną stosowali już filozofowie starożytni. Zdaniem Hartmanna od Descartesa stała się ona czołową metodą badań filozoficznych. Metoda ta zakłada całość naszego doświadczenia jako punkt wyjścia analizy kategorialnej. Na tę całość, albo w precyzyjnej terminologii B. J. Gaweckiego 88: na sumę doświadczenia, składają się doświadczenie życia codziennego, nasza praktyka życiowa, doświadczenie naukowe i filozoficzne, przy czym przez to ostatnie należy rozumieć cały historyczno-filozoficzny szereg prób, błędów i korektur razem z krytyczną wiedzą o własnych eksponentach niepewności. Autor nazywa tę sumę doświadczenia ,to, co jest dane” i rozumie przez to faktyczną świadomość filozoficzną w chwili rozpoczęcia analizy kategorialnej, uwarunkowaną myśleniem przednaukowym i naukowym oraz jakimś typem myślenia filozoficznego, którym jest refleksja nad tym, co pewne i niepewne ${ }^{89}$. Takie pojmowanie ,tego, co dane” różni się od jego ujęcia we fenomenologii ${ }^{90}$; jednocześnie takie jego ujęcie odcina się od neokantyzmu wersji marburskiej, który jako „dane” uważał tylko doświadczenie naukowe ${ }^{91}$.

IV.

Brzmi to paradoksalnie: dziś stoimy u początków nauki o kategoriach ${ }^{92}$, chociaż za właściwego twórcę tej nauki uchodzi Arystoteles. Wyróżnił on dziesięć kategorii bytowania, a więc form bytu. Kategorie te stanowią podstawową grupę orzeczników, którym - przy założeniu realizmu teoriopoznawczego Arystotelesa - odpowiadają określone grupy bytowania czy też sposoby bytowania. A. Krąpiec ${ }^{93}$ sądzi, mając na uwadze arystotelesowską tablicę kategorii, że u jej podstaw leży praw-

86 Hartmann nie przyjmuje absolutnego kryterium prawdy. W związku z tym trzeba liczyć się $w$ analizie kategorialnej z możliwością jakiegoś infinityzmu poznawczego, tzn. z niemożliwością dojścia do kresu swych poszukiwań poznawczych w tym względzie oraz $\mathrm{z}$ bezustannym i skomplikowanym sprawdzaniem wyników osiągniętych.

87 NWO, 13. 110 oraz ArW, 12.

88 Filozofia rozwoju, Warszawa 1967, 23.

89 NWO, 19.

90 Tak przynajmniej sądzi N. Hartmann w NWO, 18. Innego zdania jest Ludwig Landgrebe, Philosophie der Gegenwart, Frankfurt a. M. 1958, 64.

${ }_{91} \mathrm{NWO}, 18$.

${ }_{92} A r W$, IV.

93 Metafizyka, Poznań 1966, 306. 
dopodobnie intuicja ${ }^{94}$ rzeczywistości, którą potem Stagiryta uściślił i pogłębił analizą logiczną i gramatyczną zarazem ${ }^{95}$.

Zdecydowanego zwrotu w samym pojęciu kategorii dokonał I. Kant. Inaczej również niż Arystoteles doszedł on do ustalenia tablicy kategorii ${ }^{96}$. Rozum według Kanta jest zdølnością sądzenia i w sądzie dokonuje się połączenie podmiotu i orzeczenia pod określonym punktem widzenia. Określony punkt widzenia jest dla Kanta kategorią. Ilość kategorii dedukuje Kant z rozważania sądów pod względem jakości, ilości, relacji i modalności, z czego wnioskuje, że tyle musi być kategorii, ile jest rodzajów sądów ${ }^{97}$. W ten sposób kategorie stały się apriorycznymi formami rozumu z tym zastrzeżeniem, że przestrzeń i czas są apriorycznymi formami zmysłowości. Znaczy to, że kategorie nie zostały wyabstrahowane $z$ danych empirycznych, ale warunkują i umożliwiają doświadczenie, wprowadzając w nie ład i prawidłowość. W konsekwencji są obiektywnie ważne tylko w odniesieniu do fenomenów. Formułując to spostrzeżenie inaczej: dla kantowskiego, teoriopoznawczego problemu kategorialnego istotne pytanie było tego rodzaju: jakie znaczenie poznawcze Geltungsanspruch - mają kategorie, jaka jest ich obiektywna ważność die objektive Gültigkeit? Kant nie pytał się już o treść kategorii. Można powiedzieć, że Kant podszedł do zagadnienia kategorii w sposób formalno-logiczny, a nie ontologiczny.

$\mathrm{Na}$ tle dotychczas podejmowanych prób w kierunku wypracowania pojęcia kategorii i przedstawienia ich systemu ${ }^{98}$ nauka o kategoriach Nicolai Hartmanna stanowi najszersze przedstawienie całościowe tego zagadnienia. $\mathrm{Z}$ tym zastrzeżeniem, poczynionym wyraźnie przez samego Autora ${ }^{99}$, że jest to tylko próba i nie rości sobie ona pretensji do wyczerpania tematu, lecz ma charakter fragmentaryczny ${ }^{100}$. Można nawet bez obawy przesady powiedzieć, że w filozofii niemieckiej hartmannowskie ujęcie tego problemu jest najbardziej szczegółowe i najgłębsze.

$\mathrm{Na}$ czym polega samodzielność tej nauki o kategoriach? Chciałbym zwrócić uwagę na dwa momenty:

94 Intuicję rozumiem tutaj jako poznanie bezdyskursywne. Nie dyskutuję natury intuicji, czy jest ona poznaniem typu intelektualnego (Descartes) czy też pozaintelektualnego (Bergson).

95 Już I. Kant, Kritik der reinen Verunft $A$ 81, zarzucił Arystotelesowi brak uporządkowania kategorii według jakiejś zasady i pomieszanie form zmysłowości i form rozumu. Caspar Nink, Ontologie, Freiburg 1952, 441 przypisek 7, dodaje, że można się zgodzić na to, że ilość kategorii u Arystotelesa nie pod każdym względem jest przemyślana (philosophisch-unreflex), ale jest postawiona intuicyjnie (naturhaft-unreflex).

96 Por. np. Kritik der reinen Vernunft w wydaniu A. Messera, 86.90 albo w tł. polskim R. Ingardena t. I, [b.m.w.] 1957, 160-161, 172.

97 J. Hessen, dz. cyt., 277.

98 Warto przypomnieć poważną próbę przedstawienia systemu kategorii u Eduarda v. Hartmanna i Wilhelma Windelbanda.

${ }_{99} A r W, 129$.

100 Tamże, IX. 
1. Hartmannowskie szerokie ujęcie kategorii, w którym mieszczą się i kategorie modalności, kategorie elementarne i nawet prawa kategorialne, identyfikuje naukę o kategoriach $\mathrm{z}$ ontologią. Ontologia, zdaniem Hartmanna, zajmuje się pojęciem bytu jako takiego i jego poznaniem tzn. zagadnieniem, w jaki sposób byt jest nam dany; a ponadto problemem sposobów bytowania — ,realnością" i ,idealnością” — i ich wzajemnymi stosunkami, co jest przedmiotem tzw. analizy modalnej. Ani pytanie o pojęcie bytu jako takiego, ani też dociekanie jego sposobów istnienia nie dotyczy jeszcze samej treści bytu, tzn. nie dotyczy jego podstaw konstytutywnych. Problem bytu różnicuje się dopiero tam, gdzie badania dotyczą jego treści i podstaw i wtedy ontologia staje się nauką o kategoriach. Wobec tego naukę o kategoriach można uważać za tę część ontologii, która zajmuje się treścią pojęcia bytu rozumianego jak najszerzej. Nauka o kategoriach zajmowałaby się wtedy budową świata realnego, dzielącego się na sfery czy warstwy bytu z ich całym wewnętrznym zróżnicowaniem, stosunkami i podstawowymi elementami $i$ to tak na poziomie tego, co zasadnicze i fundamentalne jak i - przy większym skonkretyzowaniu - w odniesieniu do poszczególnych warstw. Czy takie ujęcie zagadnienia jest monizmem? Ostrożniej będzie, gdy powiem, że jest to monizujące rozumienie filozofii, skoro jest miejsce dla poszczególnych nauk filozoficznych, takich jak np. filozofia przyrody, przy czym odrębność jej metody zaznacza się w jej stosunku do concretum, jako do swego punktu wyjścia. W ogóle należy stwierdzić, że rysem charakterystycznym nauki o kategoriach jest jej ciągłe nawiązywanie do nauk szczegółowych, które dla filozofii są ,wciąż poszerzającym się polem tego, co dane”. Filozofia bowiem postępuje od doświadczenia i posługując się redukcją — od faktów dochodzi do ich podstaw.

2. Istota kategorii polega na tym, że są one formami rzeczywistości. Jest to ujęcie na wskroś obiektywistyczne. Bardzo ostrożnie formułując zarzut w stosunku do takiego poglądu na istotę kategorii wolno chyba postawić pytanie, czy aby Hartmann w sposób dostateczny uwzględnił ich pochodzenie logiczne, tzn. czy dość wyraźnie zaakcentował udział w nich myślenia?

3. Zauważono 101, że hartmannowska nauka o kategoriach jest filozoficznym opracowaniem danych, dostarczonych przez nauki szczegółowe. Zachodzi uzasadniona obawa, że w wielu wypadkach Hartmann nie wyszedł poza opis tzw. concretum i dlatego - po bardziej wnikliwym przebadaniu - należałoby się spodziewać niektórych korektur w przedmiocie jego nauki o kategoriach.

101 Heimsoeth, dz. cyt., 159. 
Niektóre referowane tutaj problemy z zakresu hartmannowskiej nauki o kategoriach przedstawił już Czesław Białobrzeski 102. I tak odwołując się explicite do dzieła Hartmanna pt. Der Aufbau der realen Welt ${ }^{103}$ zauważył, że przez kategorie rozumie Hartmann formy zawarte w naturze rzeczywistości, broniąc przeciwko Kantowi ich obiektywności ${ }^{104}$. Znaczenie ontologiczne kategorii sprecyzował potem Białobrzeski w tym kierunku, że jako formy nie przynależą one „umysłowi, lecz samym rzeczom, które umysł przyswaja w aktach poznawczych, ale nie od razu w pełni ich natury: kształtowanie form odbywa się stopniowo w miarę doskonalenia się poznania rzeczy. Inaczej mówiąc, kategorie, za których pomocą umysł porządkuje doświadczenie, nie są formami umysłu, lecz są formami bytu niezależnego od umysłu, którego funkcją jest włączanie do świadomości przedmiotów realnych oraz idealnych..." 105 Uważam, że to drugie zwłaszcza określenie bardzo trafnie streszcza pogląd Hartmanna na istotę i poznanie kategorii ${ }^{106}$.

102 Wybór pism, [b.m.w.] 1964, 127-145. Podstawy poznawcze fizyki świata atomowego, Warszawa 1956, 262-272.

103 Wybór pism, dz. cyt., 135.

104 Tamże, 136.

105 Podstawy poznawcze..., dz. cyt., 271.

$106 \mathrm{Z}$ rezerwą jednak należy się odnieść do innych wywodów $\mathrm{Cz}$. Białobrzeskiego $\mathrm{w}$ przedmiocie referowanych czy zaadoptowanych tez filozofii $\mathrm{N}$. Hartmanna. Przykładowo tylko wymienię niektóre dyskusyjne kwestie jak: pominięcie $\mathrm{w}$ budowie warstwowej rzeczywistości czwartej warstwy zobiektywizowanych zjawisk duchowych; nieadekwatne przedstawienie praw kategorialnych rządzących wg Hartmanna poszczególnymi warstwami jak i samym uwarstwieniem rzeczywistości; identyfikowanie kategorii warstw najniższych z kategoriami fundamentalnymi; pogląd jakoby wg Hartmanna warstwy bytu niższe były całkowicie niezależne od warstw wyższych czy też zarzut, że Hartmann z góry rezygnuje z całkowitej zrozumiałości świata.

\section{NICOLAI HARTMANNS BEGRIFF DER KATEGORIE}

\section{ZUSA MI E N F A S UNG}

Die Philosophie ist für N. Hartmann de facto eine Kategorienlehre. Aus diesem Grunde ist die Kategorie ein Zentralbegriff. An Hand einer Kategorialanalyse, die die innere Struktur des Seienden erforscht, gelangt Hartmann zur Formulierung des Begriffes der Kategorie. Demgemäss verstehen wir darunter die allgemeinen und konstitutiven Prinzipien des Seins. Da Hartmann in der Erkenntnislehre dem Realismus folgt, so fasst er auch die Kategorien als Prinzipien auf, die unabhängig von unserer Erkenntnis sind. Ihre Relation zum Concretum ist die, dass sie das Concretum einfach determinieren und ihr Sein besteht darin, dass sie eine Geltung für das Concretum haben. 
Hartmann unterscheidet Erkenntnis- und Seinskategorien, welche wieder für das reale oder ideale Sein ihre Geltung haben. In ihrer weiteren Unterscheidung sind sie Fundamentalkategorien, wenn sie für das ganze oder wenigstens für einen weiten Bereich des Seienden die Geltung beanspruchen, oder auch Spezialkategorien, die einer bestimmten Schicht des Seins zugeordnet sind.

Zur Erkenntnis der Kategorie gelangen wir mittels der Kategorialanalyse d.h. in der Analysis der ontischen Struktur der Gegenstände und nur in dem Grade, in welchem die Gegenstände unserer Erkenntnis zugänglich sind. Mit a.W.wir gelangen zu den Kategorien in einem Denkschluss, den man als Reduktion bezeichnet. Das Resultat einer solchen Erkenntnis erfordert eine ständige Präzision unserer Erkenntnisbemühungen und eine Kontrolle dessen, zu dem die Erkenntnis gelangt ist. Es ist ausserdem zu unterstreichen, dass für die Kategorialanalyse der Ausgangspunkt - das Concretum in Hartmanns Terminologie - ausschlaggebend ist.

Obwohl wir seit Aristoteles uns mit den Kategorien befassen, meint Hartmann, dass wir erst am Anfang einer Kategorienlehre stehen. Dies scheint in dieser Hinsicht richtig zu sein, dass wir primo den kantischen Standpunkt überwunden haben und dass, secundo, der zitierte Ausgangspunkt für eine Kategorienlehre durch die Einzelwissenschaften weitgehend bereinigt worden ist. Es ist aber dem gegenüber Gesagten auch darauf zu verweisen, dass die Gefahr besteht - und Hartmann wird ihr kaum entgangen sein - über eine pure Deskription der wissenschaftlichen Sachlage schwer hinauszukommen, geschweige der Möglichkeit weiterer philosophischer Vertiefung. 